\title{
Hubungan Pemilihan Obat dan Keberhasilan Terapi Pasien Rheumatoid Arthritis
}

\author{
Shifa A. Savitri ${ }^{1}$, Pudjiastuti Kartidjo ${ }^{1}$, Andri R. Rahmadi ${ }^{2}$, Suci N. Vikasari ${ }^{1}$ \\ ${ }^{1}$ Departemen Farmakologi dan Farmasi Klinik, Fakultas Farmasi, Universitas Jenderal \\ Achmad Yani, Cimahi, Indonesia, ${ }^{2}$ Departemen Ilmu Penyakit Dalam, Bagian \\ Reumatologi RSUP Dr. Hasan Sadikin, Bandung, Indonesia
}

\begin{abstract}
Abstrak
Rheumatoid arthritis (RA) adalah penyakit autoimun yang ditandai inflamasi kronik sistemik dan menyerang berbagai jaringan terutama sendi. Pertimbangan utama dalam pemilihan jenis obat RA adalah keberhasilan terapi dan efek samping. Penelitian ini bertujuan untuk mengevaluasi hubungan pemilihan jenis obat dan keberhasilan terapi RA pada pasien rawat jalan di salah satu rumah sakit di Bandung. Penelitian ini bersifat analitik crosssectional, dimulai dengan mengumpulkan data secara retrospektif pada 30 pasien usia produktif yang melakukan terapi RA selama tiga bulan menggunakan metilprednisolon, metotreksat, kombinasi keduanya, atau dengan obat lain. Evaluasi keberhasilan terapi dilakukan dengan membandingkan keberhasilan perbaikan nilai Disease Activity Score 28 (DAS28) sebelum dan setelah terapi, dan monitoring efek samping dilihat dari kadar hemoglobin, laju endap darah, jumlah trombosit, dan leukosit. Hasil penelitian menunjukkan bahwa $90 \%$ pasien yang berobat memperoleh terapi metilprednisolon tunggal dan/atau kombinasi dengan metotreksat atau Disease-modifying Antirheumatic Drugs (DMARDs) lain. Pasien yang menerima metilprednisolon tunggal dan metotreksat tunggal mengalami penurunan nilai DAS28 sebanyak 26,8\% dan 15,4\% jika dibandingkan dengan kondisi awal (sebelum terapi). Pasien yang menggunakan kombinasi metotreksat, metilprednisolon, dan DMARDs lain mengalami peningkatan kadar hemoglobin tertinggi sebesar 3,51\% dan penggunaan metotreksat tunggal dapat meningkatkan kadar hemoglobin sebesar $2,42 \%$. Pasien yang menerima metotreksat tunggal mengalami penurunan nilai laju endap darah tertinggi sebesar 38,46\%, penurunan trombosit tertinggi sebesar $27,16 \%$, serta penurunan leukosit tertinggi sebesar $48,80 \%$. Dapat disimpulkan bahwa meskipun sebagian besar pasien menerima terapi metilprednisolon tunggal dan/atau kombinasi dengan obat DMARDs lain, terapi menggunakan metotreksat tunggal masih merupakan pilihan utama untuk mencegah terjadinya remisi dan menurunkan risiko efek samping.
\end{abstract}

Kata kunci: DAS28, metilprednisolon, metotreksat, rheumatoid arthritis

\section{Correlation between Drug Selection and Therapeutic Goals of Rheumatoid Arthritis Patients}

\begin{abstract}
Rheumatoid arthritis (RA) is an autoimmune disease characterized by chronic systemic inflammation and attacks various tissues, especially the joints. The main consideration in choosing the type of RA drug is the success of therapy and side effects. This study aimed to evaluate the relationship between drug selection and the success of RA therapy in outpatients in a hospital in Bandung. The study was a cross-sectional analytic study, starting with collecting data retrospectively on thirty productive age patients who had three-month RA therapy using methylprednisolone, methotrexate, a combination of both or with other drugs. Evaluation of the success of therapy was done by comparing the success of the improvement of Disease Activity Score 28 (DAS28) values before and after therapy, and monitoring of side effects was seen from hemoglobin levels, blood sludge rate, platelet counts, and leukocytes. The results showed that $90 \%$ of patients seeking treatment received single and/or combination methylprednisolone therapy with methotrexate or other Disease-modifying Antirheumatic Drugs (DMARDs). Patients who received a single methylprednisolone and a single methotrexate experienced a decrease in DAS28 values of $26.8 \%$ and $15.4 \%$ compared to the beginning (before therapy). Patients who used a combination of methotrexate, methylprednisolone, and other DMARDs experienced the highest increase in hemoglobin level of $3.51 \%$ and the use of a single methotrexate could increase hemoglobin levels by $2.42 \%$. Patients who received a single methotrexate experienced a decrease in the value of the highest blood sludge rate of $38.46 \%$, the highest decrease in platelets of $27.16 \%$, and the highest decrease in leukocytes of $48.80 \%$. It can be concluded that although most patients received methylprednisolone therapy alone and/or in combination with other DMARDs, therapy using single methotrexate was still the main choice to prevent remission and reduce the risk of side effects.
\end{abstract}

Keywords: DAS28, methylprednisolone, metothrexate, rheumatoid arthritis

Korespondensi: Suci N. Vikasari, M.Si., Apt., Fakultas Farmasi, Universitas Jenderal Achmad Yani, Cimahi, Jawa Barat 40285, Indonesia, email: suci.vikasari@lecture.unjani.ac.id

Naskah diterima: 16 Agustus 2018, Diterima untuk diterbitkan: 3 Oktober 2019, Diterbitkan: 28 Desember 2019 


\section{Pendahuluan}

Rheumatoid arthritis (RA) adalah inflamasi kronik sistemik penyakit autoimun yang menyerang berbagai jaringan terutama sendi. Hal ini disebabkan oleh proliferasi sinovitis nonsuppuratif yang berkembang dan dapat menghancurkan tulang rawan artikular beserta tulang lain yang mendasari sehingga mengakibatkan radang pada sendi. ${ }^{1}$ Selain menyebabkan radang pada sendi, RA juga bisa menyerang organ tubuh lainnya, seperti pembuluh darah, kulit, mata, serta paruparu. Pasien yang menderita RA pada sendi, terutama kaki dan tangan, akan mengalami keterbatasan aktivitas sehari-hari, misalnya kesulitan berjalan dan menggunakan tangan. ${ }^{1}$

RA adalah salah satu penyakit autoimun kronis yang mendominasi wanita dibanding pria. ${ }^{1}$ Berdasarkan data hasil Riset Kesehatan Dasar (Riskesdas) 2013, prevalensi penyakit RA meningkat seiring dengan bertambahnya usia dan lebih banyak menyerang wanita, terutama usia di atas 40 tahun. Penderita RA wanita $(24,7 \%)$ lebih banyak dibandingkan laki-laki $(11,9 \%) .{ }^{3}$ Hampir $75 \%$ penderita RA merupakan wanita berusia 40-60 tahun, hal ini karena prevalensi RA berhubungan dengan penurunan jumlah estrogen, terutama setelah menopause. ${ }^{2}$ RA berkaitan dengan jumlah estrogen sebab selain bekerja sebagai hormon, estrogen juga memiliki sifat imunomodulator dengan memengaruhi interleukin-17 dari sel Th dan proses sialilasi antibodi $\mathrm{G}(\mathrm{IgG})$. $^{2,4}$ Estrogen dapat meningkatkan sel Th17 di nodus limpa dan menurunkan kadar sel Th17 di sendi. IL-7 yang berada di sendi. Lokalisasi sel Th17 di sendi pada saat awal inflamasi terjadi karena IL-7 menstimulasi sinovial fibroblast untuk menghasilkan IL-8 sehingga menyebabkan neutrofil ke sendi. ${ }^{4}$

Penilaian aktivitas penyakit RA dilakukan berdasarkan nilai Disease Activity Score 28 (DAS28) dengan menghitung sendi nyeri, sendi bengkak, laju endap darah (LED), dan skor global health yang diukur pada visual analog scale (VAS) $100 \mathrm{~mm} .{ }^{5}$ Pengobatan penyakit RA pada umumnya ditujukan untuk mengendalikan gejala dan aktivitas penyakit. Pengendalian terhadap gejala-gejala penyakit RA dilakukan menggunakan kortikosteroid, antiinflamasi nonsteroid, serta Diseasemodifying Antirheumatic Drugs (DMARDs) seperti metotreksat dan beberapa agen biologis (DMARDs biologic) seperti rituximab dan tocilizumab. ${ }^{6}$ Pemberian jenis obat terapi RA dapat dilakukan dengan pemberian obat tunggal atau kombinasi dari dua hingga tiga obat. Lee dkk. (2014) melaporkan bahwa penggunaan kombinasi metotreksat dan hidroksiklorokuin mempunyai efektivitas yang setara dengan leflunomid dalam hal mengurangi aktivitas penyakit pada saat terapi pengobatan awal RA yang parah. ${ }^{7}$ Pemilihan jenis obat RA memerlukan berbagai pertimbangan, baik dari segi kualitas, keterjangkauan harga, efek samping, serta keberhasilan terapinya. Oleh karena itu, penelitian ini bertujuan untuk mengevaluasi hubungan pemilihan jenis obat dan keberhasilan terapi RA pada pasien rawat jalan di bagian Reumatologi, Departemen Ilmu Penyakit Dalam, RSUP Dr. Hasan Sadikin Bandung.

\section{Metode}

Penelitian ini bersifat analitik cross-sectional, dimulai dengan mengumpulkan data secara retrospektif dari rekam medik pada 30 pasien rawat jalan bagian Reumatologi, Departemen Ilmu Penyakit Dalam, RSUP Dr. Hasan Sadikin periode tahun 2016-2017. Penelitian ini telah disetujui pelaksanaannya oleh Komite Etik Penelitian RSUP Dr. Hasan Sadikin Bandung melalui persetujuan etik no. LB.04.01/A05/ EC/018/I/2018.

Pada penelitian ini, pemilihan pasien dilakukan menggunakan metode nonrandom (purposive) sampling. Penentuan jumlah pasien yaitu sebanyak 30 orang dilakukan berdasar 
atas penelitian Kwak dan Kim (2017) yang menyatakan bahwa jika ukuran sampel adalah 30, maka studentized sampling distribution mendekati distribusi standar normal dan asumsi mengenai distribusi populasi tidak ada artinya sebab distribusi sampel dianggap normal berdasarkan teorema batas pusat (central limit theorem). ${ }^{8}$ Pemilihan pasien dilakukan berdasarkan kriteria inklusi usia produktif, waktu pengobatan, dan obat yang digunakan. Pasien yang dipilih merupakan pasien usia produktif (20-65 tahun). Kriteria inklusi lainnya adalah pasien melakukan pengobatan minimal tiga bulan, nilai DAS28 awal terapi $>2,6$, dalam rekam medik tercatat jumlah kunjungan pasien sebanyak tiga kali, dan pasien mendapatkan jenis obat yang sama pada saat kunjungan kedua dan ketiga (metilprednisolon, metotreksat, kombinasi keduanya atau dengan obat lain). Pasien yang dipilih adalah yang melakukan pengobatan minimal tiga bulan karena monitoring rutin laboratorium pasien RA yang menerima DMARDs biologic dan nonbiologic umumnya dilakukan setiap tiga bulan dan jika perlu dapat dilakukan perubahan regimen terapi. ${ }^{9}, 10$

DAS28 adalah indeks aktivitas penyakit RA yang tervalidasi, dengan nilai DAS28 dihitung mempertimbangkan sendi yang nyeri (TJC28), sendi bengkak (SJC28), laju endap darah (LED), skor global health (GH), dan nilai nyeri (VAS) dengan rumus: ${ }^{5,12}$

$$
\begin{aligned}
\text { DAS2 }= & 0,52 \times \sqrt{ }(28 \mathrm{TJC})+0,28 \times \sqrt{ }(28 \mathrm{SJC}) \\
& +0,70 \times \ln (\mathrm{LED})+0,014 \times \mathrm{VAS}
\end{aligned}
$$

Keterangan:

$\mathrm{TJC}=$ Jumlah sendi yang nyeri;

$\mathrm{SJC}=$ Jumlah sendi yang bengkak;

LED=Laju endap darah; dan

VAS=Visual Analogue Scale.

Nilai DAS28 yang didapatkan pada penelitian merupakan nilai yang tertera pada data rekam medik yang sudah disetujui oleh dokter penanggung jawab. Pemilihan nilai DAS28 $>2,6$ berdasarkan pada klasifikasi: pasien dengan nilai DAS28 2,6-3,2 adalah pasien RA dengan aktivitas penyakit rendah; pasien dengan nilai DAS28 3,2-5,1 adalah pasien RA dengan aktivitas penyakit sedang; dan pasien dengan nilai DAS28 $>5,1$ adalah pasien RA dengan aktivitas penyakit parah. ${ }^{11}$ Salah satu kriteria inklusi adalah kunjungan pasien maksimal hanya 3 kali dan pemilihan data dilakukan pada pasien yang mendapatkan jenis obat yang sama pada kunjungan kedua dan ketiga.

Kriteria eksklusi pada penelitian ini yaitu rekam medik pasien rawat rawat jalan bukan penderita RA, pasien tidak mendapatkan terapi metilprednisolon dan/atau metotreksat, dan rekam medik di luar periode tahun 2016-2017. Kriteria evaluasi keberhasilan terapi dilakukan dengan cara membandingkan jenis obat yang digunakan dengan keberhasilan perbaikan nilai DAS28, kadar hemoglobin, laju endap darah, dan jumlah trombosit dan leukosit. Analisis statistik data dilakukan dengan IBM SPSS 23 menggunakan paired t-test untuk melihat keberhasilan terapi dengan membandingkan data laboratorium saat sebelum dan setelah pemberian obat.

\section{Hasil}

Hasil yang diperoleh menunjukkan bahwa penderita RA pada pasien wanita sembilan kali lebih banyak dibandingkan pasien lakilaki. Berdasarkan usianya, pasien didominasi oleh kelompok usia 41-50 dan 51-60 tahun (masing-masing 30\%), dan jumlah terendah yakni kelompok usia 61-65 tahun (3\%). Data populasi pasien RA dapat dilihat pada Tabel 1.

Evaluasi penggunaan obat pada pasien secara kualitatif dilakukan untuk mengetahui ketepatan pemilihan obat, ketepatan dosis, adanya duplikasi, dan interaksi obat. Hasil penelitian menunjukkan obat yang digunakan merupakan obat golongan kortikosteroid dan 
Tabel 1 Populasi Pasien Rheumatoid Artritis di Rawat Inap Rumah Sakit Dr. Hasan Sadikin 2016-2017

\begin{tabular}{lcc}
\hline \multicolumn{1}{c}{ Karakteristik } & Jumlah & Persentase (\%) \\
\hline Jenis Kelamin & 3 & 10 \\
Laki-laki & 27 & 90 \\
Perempuan & & \\
Usia (tahun) & 5 & 17 \\
$20-30$ & 6 & 20 \\
$31-40$ & 9 & 30 \\
$41-50$ & 9 & 30 \\
$51-60$ & 1 & 3 \\
$61-65$ & 1 & \\
\hline
\end{tabular}

DMARDs, sehingga dapat dinyatakan bahwa pemilihan obat sudah dilakukan dengan tepat. Obat yang sering digunakan pada terapi RA yaitu metilprednisolon dan metotreksat tunggal atau kombinasi dengan obat-obat DMARDs lainnya (klorokuin/sulfasalazin/siklosporin/ azatriopin/leflunomid). Sebanyak 3\% pasien RA menggunakan metotreksat tunggal, 7\% metilprednisolon tunggal, 23\% kombinasi dari metilprednisolon dan metotreksat, dan 66\% kombinasi dari metilprednisolon dan/ atau metotreksat dengan obat DMARDs lain. Data obat yang digunakan pada terapi RA dapat dilihat pada Tabel 2.

Evaluasi dosis obat dilakukan berdasarkan buku Informatorium Obat Nasional Indonesia (IONI), Pusat Informasi Obat Nasional Badan Pengawas Obat dan Makanan Indonesia. ${ }^{12}$ Dari hasil penelitian, dosis yang digunakan sudah tepat, kecuali pasien yang menggunakan obat metotreksat, klorokuin dan metilprednisolon. Pada penelitian ini, penggunaan metotreksat dinyatakan tidak tepat disebabkan dosis yang digunakan $<7,5 \mathrm{mg}$ yaitu 2 tablet per minggu atau yang setara dengan $5 \mathrm{mg}$. Penggunaan klorokuin dinyatakan tidak tepat karena dosis yang digunakan $<250 \mathrm{mg}$ yaitu dosis $200 \mathrm{mg}$, dan penggunaan metilprednisolon dinyatakan tidak tepat disebabkan dosis penggunaanya $>7,5 \mathrm{mg}$ yaitu dosis $8 \mathrm{mg}$. Apabila dosis yang diberikan kurang atau lebih dari yang seharusnya, maka terapi tidak akan tercapai. Data penggunaan dosis obat pada pasien RA dapat dilihat pada Tabel 3.

Evaluasi keberhasilan terapi RA dilakukan dengan cara membandingkan perbaikan nilai DAS28, kadar hemoglobin, laju endap darah, jumlah trombosit dan leukosit pada awal dan akhir terapi selama 3 bulan. Berdasarkan hasil evaluasi data nilai DAS28 yang ditunjukkan dalam Tabel 4, dapat diketahui bahwa pasien yang mendapatkan metilprednisolon tunggal mengalami penurunan nilai DAS28 tertinggi sebesar 26,8\%, pasien yang mendapatkan metotreksat tunggal mengalami penurunan nilai DAS28 sebesar $15,4 \%$, sedangkan pasien

Tabel 2 Obat yang Digunakan pada Terapi Rheumatoid Arthritis

\begin{tabular}{lcc}
\hline \multicolumn{1}{c}{ Obat } & Jumlah & Persentase (\%) \\
\hline Metotreksat & 1 & 3 \\
Metilprednisolon & 2 & 7 \\
Metotreksat + Metilprednisolon & 7 & 23 \\
Metotreksat + DMARDs lain & 2 & 7 \\
Metilprednisolon + DMARDs lain & 12 & 39 \\
Metotreksat + Metilprednisolon + DMARDs lain & 6 & 20
\end{tabular}

Keterangan: DMARDs= Disease-modifying Antirheumatic Drugs (DMARDs lain=klorokuin/sulfasalazin/siklosporin/azatriopin/ leflunomid) lain=klorokuin/sulfasalazin/siklosporin/azatriopin/leflunomid 
Tabel 3 Evaluasi Penggunaan dosis Obat pada Pasien RA

\begin{tabular}{lccc}
\hline \multirow{1}{*}{ Obat } & Dosis $^{\mathbf{1 2}}$ & \multicolumn{2}{c}{ Jumlah pasien } \\
\cline { 3 - 4 } & & Tepat & Tidak Tepat \\
\hline Metotreksat & $7,5-20 \mathrm{mg} / \mathrm{minggu}$ & 13 & 1 \\
Metilprednisolon & $<7,5 \mathrm{mg}$ & 26 & 1 \\
Klorokuin & $250 \mathrm{mg}$ & 7 & 0 \\
Sulfasalazin & $500-1000 \mathrm{mg}$ & 9 & 0 \\
Siklosporin & $2,5 \mathrm{mg} / \mathrm{kg} \mathrm{BB} /$ hari & 2 & 0 \\
Azatriopin & $3 \mathrm{mg} / \mathrm{kg} \mathrm{BB} / \mathrm{hari}$ & 1 & 0 \\
Leflunomid & $10-20 \mathrm{mg}$ & 1 & \\
\hline
\end{tabular}

yang mendapat terapi kombinasi metotreksat dan metilprednisolon mengalami penurunan nilai DAS28 terendah sebesar 2,9\% jika dibandingkan kondisi awal sebelum terapi. Berdasarkan nilai DAS28 pada saat awal terapi yang hampir sama pada semua pasien ( $>0,05)$, tidak ada kriteria batas minimum nilai DAS28 untuk penentuan jenis obat yang digunakan pada terapi RA.

Berdasarkan data hemoglobin sebelum dan setelah terapi (Tabel 4), diketahui pasien yang menggunakan kombinasi metotreksat, metilprednisolon, serta DMARDs lainnya mengalami peningkatan kadar hemoglobin tertinggi yakni sebesar 3,51\%, pasien yang menggunakan metotreksat tunggal mengalami peningkatan sebesar $2,42 \%$, sedangkan pasien yang mendapatkan kombinasi metotreksat dan DMARDs lain mengalami penurunan kadar hemoglobin sebesar 4,93\% $(p<0,05$ jika dibandingkan penggunaan metotreksat tunggal). Berdasarkan data nilai laju endap darah sebelum dan setelah terapi (Tabel 4), diketahui bahwa pasien yang mendapatkan metotreksat tunggal mengalami penurunan nilai laju endap darah tertinggi yakni sebesar $38,46 \%$, sedangkan pasien yang mendapatkan terapi kombinasi dari metilprednisolon dan DMARDs lain mengalami peningkatan laju endap darah sebesar 22,34\%.

Berdasarkan hasil nilai trombosit sebelum dan setelah terapi (Tabel 4), diketahui pasien yang menggunakan metotreksat tunggal mengalami penurunan trombosit tertinggi sebesar $27,16 \%$. Hal ini berbanding terbalik dengan pasien yang menggunakan kombinasi metilprednisolon dan DMARDs lain yang mengalami kenaikan jumlah trombosit yaitu sebesar $0,82 \%$. Berdasarkan nilai leukosit pada awal dan akhir terapi (Tabel 4), diketahui bahwa pasien yang menggunakan metotreksat tunggal mengalami penurunan nilai leukosit tertinggi sebesar 48,80\%, hal ini berbanding terbalik dengan pasien yang menggunakan kombinasi metotreksat, metilprednisolon dan DMARDs lainnya yang mengalami kenaikan nilai leukosit tertinggi yaitu sebesar 19,71\%.

Berdasarkan adanya peningkatan kadar hemoglobin dan penurunan laju endap darah, penggunaan metotreksat tunggal memberikan efek terbaik pada terapi penderita RA. Selain itu, penggunaan metotreksat tunggal pada terapi RA juga dapat menurunkan jumlah trombosit dan leukosit tertinggi dibandingkan metilprednisolon atau pada saat metotreksat dikombinasikan dengan DMARDs lain.

\section{Pembahasan}

Pada penelitian ini, pemilihan dan penggunaan obat DMARDs telah tepat indikasi. Hal ini ditunjukkan dengan kesesuaian pemilihan dengan diagnosis dan data laboratorium saar sebelum terapi. Hasil penelitian menunjukkan bahwa metilprednisolon dan/atau metotreksat tunggal atau kombinasi dengan sulfasalazin 
Tabel 4 Hasil Data Klinis Pasien Sebelum dan Setelah Terapi

\begin{tabular}{|c|c|c|c|c|c|c|}
\hline Parameter & $\begin{array}{l}\text { Meto- } \\
\text { treksat }\end{array}$ & $\begin{array}{c}\text { Metilpred- } \\
\text { nisolon }\end{array}$ & $\begin{array}{c}\text { Metotreksat } \\
+ \text { Metilpred- } \\
\text { nisolon }\end{array}$ & $\begin{array}{c}\text { Metotreksat } \\
+ \text { DMARDs } \\
\text { lain }\end{array}$ & $\begin{array}{c}\text { Metilpred- } \\
\text { nisolon + } \\
\text { DMARDs } \\
\text { lain }\end{array}$ & $\begin{array}{c}\text { Metotreksat } \\
+ \text { Metilpred- } \\
\text { nisolon + } \\
\text { DMARDs } \\
\text { lain }\end{array}$ \\
\hline \multicolumn{7}{|l|}{ DAS28 } \\
\hline Awal terapi & $3,9 \pm 0$ & $4,1 \pm 1,4$ & $3,5 \pm 0,9$ & $4,4 \pm 1,9$ & $3,9 \pm 1,0$ & $3,5 \pm 1,4$ \\
\hline Akhir terapi & $3,3 \pm 0$ & $3,0 \pm 0,6$ & $3,4 \pm 0,9$ & $3,5 \pm 0,3$ & $3,7 \pm 1,1$ & $2,8 \pm 0,4$ \\
\hline$\%$ penurunan & 15,4 & 26,8 & 2,9 & 20,5 & 5,1 & 20,0 \\
\hline \multicolumn{7}{|c|}{ Hemoglobin (g/dL) } \\
\hline Awal terapi & $12,4 \pm 0$ & $13,4 \pm 0,3$ & $12,9 \pm 1,2$ & $14,3 \pm 1,1$ & $12,8 \pm 2,1$ & $11,4 \pm 2,1$ \\
\hline Akhir terapi & $12,7 \pm 0$ & $13,2 \pm 0,4$ & $13,1 \pm 1,4$ & $13,6 \pm 1,1$ & $13,0 \pm 2,4$ & $13,8 \pm 2,2$ \\
\hline$\%$ penurunan & 2,42 & $-1,82$ & 1,50 & $-4,93$ & 1,58 & 3,51 \\
\hline \multicolumn{7}{|l|}{ LED (mm/jam) } \\
\hline Awal terapi & $52,0 \pm 0$ & $44,0 \pm 4,2$ & $54,1 \pm 24,1$ & $38,0 \pm 25,5$ & $41,5 \pm 26,1$ & $32,3 \pm 18,8$ \\
\hline Akhir terapi & $32,0 \pm 0$ & $32,0 \pm 9,9$ & $54,4 \pm 26,9$ & $39,5 \pm 26,2$ & $43,0 \pm 23,1$ & $21,0 \pm 4,5$ \\
\hline$\%$ penurunan & 38,46 & 28,02 & 1,07 & $-4,29$ & $-22,34$ & 12,02 \\
\hline \multicolumn{7}{|c|}{ Trombosit (x 10 $\left.10^{3} / \mathrm{mm}^{3}\right)$} \\
\hline Awal terapi & $335,0 \pm 0$ & $345,5 \pm 6,4$ & $395,3 \pm 78,3$ & $364,0 \pm 62,2$ & $362,5 \pm 77,4$ & $348,8 \pm 59,1$ \\
\hline Akhir terapi & $244,0 \pm 0 *$ & $334,0 \pm 82,0$ & $338,0 \pm 43,6$ & $305,5 \pm 9,2$ & $361,4 \pm 102,2$ & $336,5 \pm 92,1^{*}$ \\
\hline$\%$ penurunan & 27,16 & 3,53 & 12,83 & 15,05 & $-0,82$ & 3,56 \\
\hline \multicolumn{7}{|c|}{ Leukosit $\left(x 1^{3} / \mathrm{mm}^{3}\right)$} \\
\hline Awal terapi & $12,5 \pm 0$ & $10,0 \pm 6,5$ & $11,1 \pm 2,1$ & $9,7 \pm 1,5$ & $9,7 \pm 3,1$ & $8,5 \pm 2,8$ \\
\hline Akhir terapi & $6,4 \pm 0$ & $8,1 \pm 1,5$ & $9,7 \pm 4,4$ & $8,5 \pm 2,3$ & $10,4 \pm 6,4$ & $10,6 \pm 3,4$ \\
\hline$\%$ penurunan & 48,80 & 2,86 & 10,76 & 12,94 & $-10,84$ & $-19,71$ \\
\hline
\end{tabular}

Keterangan: DAS28=Disease Activity Score-28; LED=Laju endap darah; DMARDs=Disease-modifying Antirheumatic Drugs (DMARDs lain=klorokuin/sulfasalazin/siklosporin/azatriopin/leflunomid); ${ }^{*} \mathrm{p}<0,05$, menggunakan paired $t$-test

atau klorokuin merupakan obat yang sering digunakan pada terapi RA. Pada penelitian ini, pemberian metilprednisolon tunggal dapat menurunkan nilai DAS28 paling baik dibandingkan obat yang lainnya. Faktor yang diperhitungkan pada penilaian DAS28 adalah jumlah sendi yang nyeri, jumlah sendi yang bengkak dan derajat nilai nyeri yang dirasakan pasien. ${ }^{5,11}$ Oleh karena itu, metilprednisolon akan memengaruhi penurunan nilai DAS28 dibandingkan obat lain disebabkan perannya sebagai antiinflamasi dan antinyeri, serta menjadi pertimbangan saat terjadi saat kondisi kekambuhan RA terjadi (flare). ${ }^{13}$ Seperti yang telah disebutkan, efek dari kortikosteroid pada terapi RA adalah sebagai antiinflamasi, selain itu kortikosteroid juga dapat berperan sebagai imunosupresan. Efek antiinflamasi dihasilkan dari berbagai aktivitas biologis, antara lain kemampuan untuk menghambat respon antigenik dari makrofag dan leukosit; penghambatan permeabilitas pembuluh darah dengan menghambat pelepasan histamin dan aksi kinin; penurunan kadar prostaglandin, leukotrien, dan faktor pengaktivasi platelet akibat aktivasi fosfolipase A2; penurunan ekspresi siklooksigenase dan pembentukan nitrit oksida; serta penghambatan produksi dan pelepasan kemokin dan sitokin termasuk interleukin (IL) 1/IL-1, IL-2, IL-3, IL-6, TNF- $\alpha$, dan faktor stimulasi koloni granulosit makrofag (GM-CSF). ${ }^{14}$ Hasil penelitian ini menunjukkan bahwa jenis obat yang paling banyak digunakan pada terapi RA pasien 
rawat jalan adalah metilprednisolon, hal ini sesuai dengan laporan Garner dkk. (2014) yang menyatakan bahwa glukokortikoid dapat digunakan pada fase awal terapi penyakit RA dengan tujuan untuk mencegah aktivitas penyakit. Penggunaan glukokortikoid dalam jangka panjang memerlukan monitoring efek samping osteoporosis dan risiko infeksi. ${ }^{15}$ Meskipun penggunaan prednisolon sebagai bridging therapy dengan penurunan dosis tidak direkomendasikan, namun berdasarkan bukti medis, dosis rendah prednisolon 7,5 mg setiap hari dapat ditambahkan pada terapi DMARDs (metotreksat) pada pasien RA awal. $^{14}$

Selain metotreksat, pada hasil penelitian ini, beberapa jenis DMARDs lain digunakan pada terapi RA yaitu sulfasalazine, klorokuin dan leflunomide. Sulfasalazin merupakan senyawa hasil kombinasi antiinflamasi, asam salisiat, serta antibakteri sulfapiridin yang digabungkan dengan ikatan azo. Oleh karena itu, sulfasalazin dapat digunakan pada RA aktif dan akan menurunkan inflamasi. ${ }^{16}$ Klorokuin digunakan sebagai terapi tambahan pada penderita RA dalam penelitian ini. Klorokuin dapat bekerja dalam suasana asam, seperti lisosom, yang memberikan pengaruh terhadap fungsi reseptor, produksi autoantibodi dan sel NK, penghambatan proses intraselular dan sekresi protein, penurunan proliferasi limfosit, dan produksi sitokin. ${ }^{17,18}$

Hasil yang diperoleh dalam penelitian menunjukkan bahwa pemilihan jenis obat tidak memiliki hubungan dengan nilai DAS28 awal, laju endap darah, hemoglobin, trombosit, dan leukosit. Berdasarkan rekomendasi dari American College of Rheumatology (2015), penggunaan monoterapi DMARDs lebih diutamakan dibanding kombinasi, meskipun nilai aktivitas penyakit (DAS28) termasuk kategori remisi sedang dan tinggi. ${ }^{9}$ Shinde dkk. (2014) menyebutkan bahwa metotreksat merupakan pilihan utama terapi RA ditinjau dari efektivitas, profil keamanan dan biaya. ${ }^{19}$
Penggunaan kombinasi DMARDs dilakukan terutama pada kasus-kasus yang tidak respon dengan metotreksat tunggal, dan penggunaan awal glukokortikoid dalam dosis tinggi tidak memberikan keuntungan terhadap pasien RA dengan prognosis buruk. ${ }^{20}$

Salah satu manifestasi klinik RA adalah anemia yang ditandai adanya peningkatan laju endap darah dan penurunan hemoglobin, serta trombositosis dan eosinofilia. ${ }^{21}$ Hasil yang diperoleh pada penelitian menunjukkan bahwa metotreksat (yang dikombinasikan dengan asam folat) dapat meningkatkan kadar hemoglobin, menurunkan laju endap darah, serta menurunkan jumlah trombosit dan leukosit. Metotreksat bekerja dengan cara menghambat enzim pada jalur asam folat dengan menghambat biosintesis purin dan pirimidin sehingga terjadi gangguan replikasi DNA dan proliferasi sel. ${ }^{22}$ Metotreksat dapat menyebabkan ganggun hematologi antara lain mielosupresi dan pansitopenia (trombositopenia, anemia megaloblastik dan leukopenia). ${ }^{22}$ Efek samping dari metotreksat (anemia) yang dapat diprediksi menyebabkan penggunaan metotreksat selalu disertai asam folat. ${ }^{19}$

Berdasarkan data yang diperoleh dalam penelitian ini, terlihat bahwa metotreksat merupakan jenis obat yang utama pada terapi pasien RA. Penelitian ini memperkuat bukti pemilihan metotreksat sebagai terapi utama sesuai dan masih relevan dengan pedoman penatalaksanaan RA yang dikeluarkan oleh Perhimpunan Reumatologi Indonesia.

RA merupakan penyakit kronis dan salah satu faktor yang menunjang keberhasilan terapi adalah kepatuhan pasien dalam minum obat. Untuk studi selanjutnya, peneliti disarankan untuk menganalisis kepatuhan penggunaan obat DMARDs selama terapi. Pengumpulan data dalam penelitian ini dilakukan secara retrospektif dari rekam medik, dan hal ini merupakan salah satu keterbatasan penelitian ini. Untuk penelitian lebih lanjut, disarankan 
agar pengambilan data dapat dilakukan secara konkuren. Salah satu keterbatasan lain pada penelitian ini adalah keterbatasan data rekam medik mengenai durasi dalam penggunaan obat sehingga pasien yang baru menggunakan obat (new user) tidak dapat dibedakan dengan pasien yang menggunakan obat dalam jangka waktu lama (prevalent user). Meskipun lama penggunaan obat dapat memengaruhi risiko resistensi, terutama pada transporter $\mathrm{ABC}$, perlu pengamatan yang lebih dalam mengenai manisfestasi klinik dan pengujian aktivitas transporter $\mathrm{ABC}$ pada sel yang relevan dengan penyakit RA. ${ }^{23}$

\section{Simpulan}

Meskipun pada hasil penelitian ini obat yang sering digunakan dalam terapi RA adalah metilprednisolon tunggal atau kombinasi, namun ditinjau dari adanya penurunan nilai DAS28, laju endap darah, jumlah trombosit dan leukosit, serta adanya peningkatan kadar hemoglobin, metotreksat masih merupakan pilihan utama untuk mencegah terjadi remisi dan menurunkan risiko efek samping. Monitor fungsi organ pada penggunaan metotreksat dan metilprednisolon jangka panjang perlu dilakukan.

\section{Pendanaan}

Penelitian ini tidak didanai oleh sumber hibah manapun.

\section{Konflik Kepentingan}

Seluruh penulis menyatakan tidak terdapat potensi konflik kepentingan dengan penelitian, kepenulisan (authorship), dan atau publikasi artikel ini.

\section{Daftar Pustaka}

1. McInnes IB, Schett G. The pathogenesis of rheumatoid arthritis. N Engl J Med. 2011;365(23):2205-19. doi: 10.1056/NE JMra1004965.

2. Engdahl C, Bondt A, Harre U, Raufer J, Pfeifle R, Camponeschi A, et al. Estrogen induces St6gall expression and increases IgG sialylation in mice and patients with rheumatoid arthritis: A potential explanation for the increased risk of rheumatoid arthritis in postmenopausal women. Arthritis Res Ther. 2018;20(1):84. doi: 10.1186/s13075018-1586-z.

3. Kementerian Kesehatan Republik Indonesia. Riset kesehatan dasar 2013. Jakarta: Kementerian Kesehatan Republik Indonesia; 2013.

4. Andersson A, Stubelius A, Karlsson MN, Engdahl C, Erlandsson M, Grahnemo L, et al. Estrogen regulates $\mathrm{T}$ helper 17 phenotype and localization in experimental autoimmune arthritis. Arthritis Res Ther. 2015;17:32. doi: 10.1186/s13075-015054 $8-\mathrm{y}$.

5. Santosa D, Hidayat R, Prasetyo M, Nugroho P. Diagnostic values of DAS28 and DAS28-squeeze in evaluating rheumatoid arthritis disease. Ind J Rheumatol. 2016;8(2):10-4.

6. Wasserman AM. Diagnosis and management of rheumatoid arthritis. Am Fam Physician. 2011;84(11):1245-52.

7. Lee EB, Fleischmann $R$, Hall $S$, Wilkinson B, Bradley JD, Gruben D, et al. Tofacitinib versus methotrexate in rheumatoid arthritis. N Engl J Med. 2014; 370(25):2377-86. doi: 10.1056/NEJMoa1 310476

8. Kwak SG dan Kim JH. Central limit theorem: The cornerstone of modern statistics. Korean J Anesthesiol. 2017;70 (2):144-56. doi: 10.4097/kjae.2017.70.2. 144

9. Singh JA, Saag KG, Bridges L, Akl EA, Bannuru RR, Sullivan MC, et al. 2015 American College of Rheumatology 
Guideline for the treatment of rheumatoid arthitis. Arthritis Rheumatol. 2016;68(1): 1-26. doi: 10.1002/art.39480

10. Rigby WFC, Lampl K, Low JM, Furst DE. Review of routine laboratory monitoring for patients with rheumatoid arthritis receiving biologic or nonbiologic DMARDs. Int J Rheumatol. 2017;2017: 9614241. doi: 10.1155/2017/9614241.

11. Salaffi F, Ciapetti A. Clinical disease activity assessments in rheumatoid arthitis. Int J Clin Rheumatol. 2013;8(3)347-60. doi: 10.2217/IJR.13.24

12. Badan Pengawas Obat dan Makanan. Informatorium Obat Nasional Indonesia (IONI) Pelayanan Informasi Obat (PIO) Nasional [diunduh 26 Mei 2018]. Tersedia dari: http://pionas.pom.go.id/ioni

13. Wilsdon TD. Managing the drug treatment of rheumatoid arthritis. Aust Prescr. 2017; 40(2):51-8. doi: 10.18773/austprescr.201 7.012

14. Iyalomhe GBS, Iyalomhe SI. Current use of corticosteroids in rheumatology. Int Res J Pharm Pharmacol. 2013;3(6):85-90.

15. Garner R, Ding T, Deighton C. Management of rheumatoid arthritis. Med. 2014;42(5):237-42. doi: 10.1016/j.mpme d.2014.02.004

16. Aggarwal D, Abraham S. Rheumatoid arthritis treatments: A historical perspective. JSM Arthritis. 2016;1(2):1011.

17. An J, Minie M, Sasaki T, Woodward JJ, Elkon KB. Antimalarial drugs as immune modulators: New mechanisms for old drugs. Annu Rev Med. 2017;68(30):1-14. doi: 10.1146/annurev-med-043015-1234 53.

18. Katz SJ, Russell AS. Antimalarials for the treatment of rheumatic disease: Recent advances and future use. Int J Clin Rheumatol. 2012;7(3):239-41. doi: 10.2 217/ijr.12.9

19. Shinde CG, Venkatesh MP, Kumar TMP, Shivakumar HG. Methotrexate: A gold standard for treatment of rheumatoid arthritis. J Pain Palliat Care Pharmacother. 2014;28(4):351-8. doi: 10.3109/1536028 8.2014 .959238 .

20. Onuora S. Rheumatoid arthritis: Methotrexate and bridging glucocorticoids in early RA. Nat Rev Rheumatol. 2014; 10(12):698. doi: 10.1038/nrrheum.2014. 197

21. Arul R, Kumar PP. Study of hematological profile in rheumatoid arthritis patients IOSR J Dent Med Sci. 2016;15(9):96100. doi: 10.9790/0853-15090496100

22. Rajnics P, Kellner VS, Kellner A, Karadi E, Kollar B, Egyed M. The hematologic toxicity of methotrexate in patiens with autoimmune disorders. J Neoplasm. 2017; 2(1):1-6. doi: 10.217672576-3903.100010

23. Márki-Zay J, Jakab KT, Szerémy P, Krajcsi P. MDR-ABC transporters: Biomarkers in rheumatoid arthritis. Clin Exp Rheumatol. 2013;31(5):779-87. 